\title{
Teologi, allmenn vitenskapsmoral, kultur- og samfunnsfagenes normativitet
}

Published in Kirke \& Kultur 2005 (3): 409 - 421

Ragnvald Kalleberg, Universitety of Oslo

ragnvald.kalleberg@sosiologi.uio.no

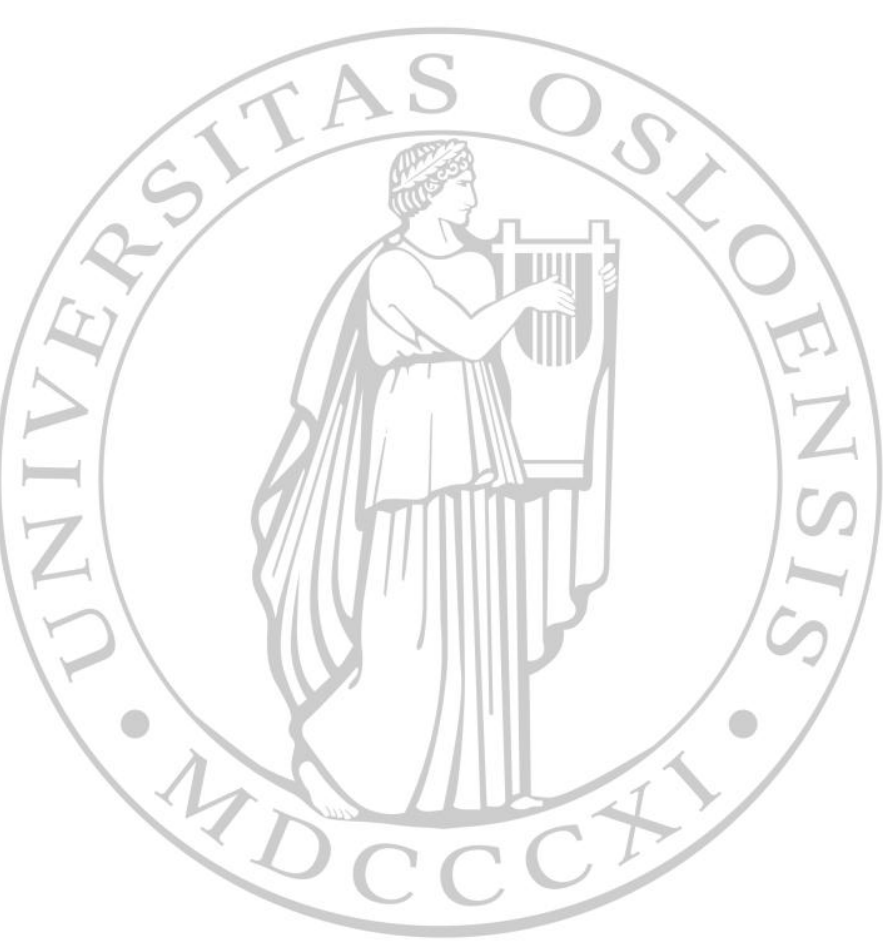

Department of Sociology and Human Geography University of Oslo

P.O.Box 1096 Blindern

N-0317 OSLO Norway

Telephone: $\quad+4722855257$

Fax: $\quad+4722855253$

Internet: http://www.iss.uio.no 


\section{Teologi, allmenn vitenskapsmoral, kultur- og samfunnsfagenes normativitet}

De tre norske forskningsetiske komiteene dekker alle fagområder, ordnet i tre mangfoldige fagfamilier: helsefag (NEM), naturvitenskapelige og teknologiske fag (NENT), kultur- og samfunnsfag (NESH). Teologiske fag hører til innenfor ansvarsområdet til NESH, «Den nasjonale forskningsetiske komité for samfunnsvitenskap og humaniora». KUF omtalte i 1990 disse fagområdene som «de normative vitenskapelige disipliner», en interessant benevnelse jeg kommer tilbake til. NESH har utarbeidet forskningsetiske retningslinjer for sine fagområder. Den første versjonen forelå i 1993, en revidert versjon kom seks år senere (NESH 1999). En viss usikkerhet om teologiens status og plassering som vitenskap avspeiles kanskje i at man på forsiden av begge versjoner markerer at retningslinjene dreier seg om samfunnsvitenskap, humaniora og juss. Teologi nevnes ikke, men forutsettes nok litt uklart å ligge innenfor humaniora.

I de 15 årene NESH har vært i virksomhet, har man hele tiden hatt teologer som medlemmer. Det har fulgt naturlig av mandatet, hvor det heter at man også skal ha medlemmer med fagkompetanse i etikk. Daværende Kirke utdannings- og forskningsdepartement (KUF) presiserte dessuten at komitéens ansvarsområde innbefattet både juss og teologi. I den reviderte versjonen av Forskningsetiske retningslinjer som var ute til nasjonal høring våren 2005, gjøres det klart at både juss og teologi er inkludert.

NESH arrangerte høsten 2002 et heldagsseminar om akademisk frihet i teologisk forskning (se NESH 2003). Foranledningen var den såkalte Henriksen-saken ved Menighetsfakultetet (MF), en sak som preget norske massemedier i 2001 (se f.eks. Henriksen, Dokka og Skarsaune, 2001). Sakens innholdsmessige kjerne var motstridende svar på spørsmålet om det finnes tungtveiende etiske grunner mot at homofile kan leve i partnerskap. Professor Jan-Olav Henriksen mente at det ikke forelå slike grunner. MF valgte å 
få Henriksen overført til et annet professorat og ta ham vekk fra undervisning i etikk. Som NESH-sak dreide det seg om akademisk frihet, inklusive forskningsbasert undervisning. Dette var første gang i komitéens 12 år lange historie at forskningsetiske problemer i teologifag ble satt på dagsorden. Teologer hadde blitt brukt som etikk-eksperter, men komitéen hadde ikke tatt for seg forskningsetiske problemer innenfor de teologiske fag.

Året etter drøftet NESH noen forskningsetiske aspekter ved en konflikt ved Misjonshøgskolen i Stavanger. Saken dreide seg om de problemer som oppsto ved en luthersk institusjon etter at en vitenskapelig ansatt, professor Ola Tjørhom, konverterte til katolisismen. I likhet med professor Bernt Oftestad ved MF, som konverterte noen år før, fikk han ikke lenger anledning til å undervise på sine spesialområder. NESH hadde ikke Tjørhoms situasjon oppe som egen sak, men arrangerte et internseminar for å belyse noen prinsippielle sider ved forskningens og den forskningsbaserte undervisningens betingelser ved private, teologiske høgskoler.

Våren 2004 ble spørsmålet om akkreditering av Menighetsfakultetet som vitenskapelig høgskole, satt på den offentlige dagsorden. Flertallet i den sakkyndige komité som "Nasjonalt organ for kvalitet i utdanningen" (NOKUT) nedsatte, anbefalte ikke akkreditering. I svaret til NOKUT tok MF inn over seg den sakkyndige komités kritikk og informerte om at de ville utlyse vitenskapelige stillinger og at MFs lærerråd ikke skulle brukes som instans i personalsaker. MF la vekt på at «de normer for forskningsfrihet som er nedfelt i NESHs retningslinjer....gjelder uavkortet ved fakultetet». ${ }^{1}$ Etter dette anbefalte NOKUT akkreditering.

I november 2004 arrangerte NESH et åpent møte om teologi og akademisk frihet, der sentrale temaer ble drøftet: a) Åpen utlysning av eller kalling av bestemte personer til vitenskapelige stillinger. b) Problemer i det å være både akademisk forskningsinstitusjon og konfesjonsbundet presteutdanning. c) Legitim og illegitim kollegial kontroll i institusjoner med en «bekjennelsesmessig forpliktelse». d) Forskningsbasert undervisning. Finnes det vitenskapelig akseptable grunner for at en kompetent forsker ved en luthersk institusjon mister undervisnings- og veiledningskompetanse ved overgang til katolisisme?

I det følgende ser jeg nærmere på disse temaene, med utgangspunkt $\mathrm{i}$ generelle synspunkter på vitenskapsmoral og forskningsetikk. Jeg skriver ikke her på vegne av NESH, men som sosiolog med vitenskapssosiologi, vitenskapsteori og forskningsetikk som spesialområder. 


\section{Vitenskapenes enhet og forskjellighet}

Hva kreves for at et fag skal være en vitenskap? Finnes det felles forskningsetiske retningslinjer for alle vitenskaper? Slike spørsmål utforskes innenfor det flerfaglige fagområdet vitenskapsteori. For noen få tiår siden sto hele familien av kultur- og samfunnsfag utsatt til i diskusjoner om hvilke fag som egentlig var vitenskaper. Vurdert ut fra datidens krav i positivistisk vitenskapsteori, med de vellykkede naturfag som modeller, var det knapt noen av kultur- og samfunnsfagene som på 1950- og 1960-tallet fortjente betegnelsen vitenskap. Et unntak kunne kanskje gjøres for økonomifaget, med sin omfattende bruk av kvantitative data og matematiske modeller. Indikasjoner på at et fag kunne regnes som vitenskap, var gjerne kvantitative data, årsaksforklaring av hendelser og helst også at man søkte å forutsi fremtidige hendelser, slik astronomer forutsier solformørkelser.

Positivistisk vitenskapsteori ble utsatt for omfattende kritikk i løpet av 1960- og 1970-tallet. Diskusjonene dreide seg om naturfagsinspirerte krav til vitenskap kunne anvendes på kultur-og samfunnsfag. Det ble argumentert for at man i disse fagene hadde en særegen, hermeneutisk tilgang til det studerte felt og at disse fagene også var «kritiske» eller «normative» disipliner. Her kommer man heller ikke utenom innsikten om at mennesket som et delvis selvbestemmende vesen, er et handlende subjekt og ikke bare et objekt det hender noe med. Disse forhold preger ikke naturfagene, noe som må få konsekvenser for fagområdenes grunnlagsspørsmål og vitenskapsteori. ${ }^{2}$

Positivistisk vitenskapsteori er preget av en «etnosentrisk feilslutning», som ligger snublende nær, både i dagligliv og fagliv. Et enkelt eksempel er at nordmenn umiddelbart kan oppfatte det slik at de innfødte kjører på feil side av veien i England. Feilslutningen hviler på manglende bevissthet om hvor langt gyldigheten av egne vaner, konvensjoner, oppfatninger og vurderinger strekker seg. Men fornuftig forståelse omfatter også innsikt om oppfatningers gyldighetsområde. Det som er riktig på et sted eller i en sammenheng, kan være feil i andre sammenhenger. Flertallsbeslutninger er fornuftig i politikk, men illegitimt i vitenskap. Årsaksforklaringer av den type man finner i utforskning av kjemiske prosesser, f.eks. Boyle-Mariottes lov, er velegnede for å forstå sammenhengen mellom gassers trykk og volum, men ubrukelige for å forstå samspillet mellom kjemikere.

I positivistisk tradisjon søkte man å finne frem til krav som skulle gjelde for alle vitenskaper (unity of science). Det var en viktig bestrebelse. Problemet var at man søkte enheten på et for konkret nivå, som i de samme krav 
til data (kvantifisering), metoder (eksperimenter), (årsaks)forklaringer og forutsigelser. I etterpositivistisk vitenskapsteori kan og bør man fortsatt insistere på trekk som er felles for alle vitenskaper (vitenskapenes enhet), men søke dem på et mer abstrakt nivå. Det som er felles er mer generelle intellektuelle og forskningsetiske krav, både til individer og institusjoner. Det omfatter krav til pålitelig dokumentasjon, konsistens, vitenskapelig redelighet, fagfellekontroll og faglig uavhengighet. Den felles ambisjonen er at vitenskapssamfunn bare skal være styrt av kraften i de bedre argumenter.

Innenfor en slik overordnet vitenskapenes enhet, kan man så snakke om vitenskapens forskjellighet. I kultur- og samfunnsfag får man bare kontakt med det studerte felt gjennom å «kommunisere» med det, om det nå er via tolking av århundregamle tekster eller via samtaler med levende mennesker. Disse fagene er hermeneutiske. Selv om fysikere og kjemikere hadde villet, kan de ikke kommunisere med sitt gjenstandsområde, men er henvist til bare å observere det.

Kultur- og samfunnsfagene er også «normative» («kritiske»). Det har blitt tolket på mange måter. Noen av tolkingene er uholdbare, som når noen positivismekritikere på 1970- og 1980-tallet trakk den lærdom at når man ikke kunne være verdinøytral, så burde man tilkjennegi hva slags interesser man selv sluttet seg til. Disse kunne imidlertid ikke begrunnes, bare deklareres. Samfunnsvitere sluttet seg dengang gjerne til «radikale» interesser. I en kronikk i forbindelse med Henriksen-saken, ga Oskar Skarsaune uttrykk for et tilsvarende synspunkt. Han viste til nye vitenskapsidealer og et "paradigmeskifte»: «Det er blitt klart for mange at heller ikke den vitenskapelige forskning finner sted $i$ et moralsk og verdimessig «nøytralt» vakuum, og at all forskning er basert i visse grunnleggende verdivalg».

Slik anti-positivisme og vitenskapsforståelse hviler som regel på en underforstått forestilling om at normative synspunkter ikke kan diskuteres rasjonelt, ikke styrkes eller svekkes med argumenter. Normer og vurderinger hviler heller på vaner, følelser, noe man har bestemt seg for eller tror på. Men hvis det er tilfellet, hører slike temaer ikke til innenfor vitenskapelige fag. Legitime vitenskapelige spørsmål forutsetter at de kan diskuteres på en slik måte at de bedre argumenter kan drive de dårligere ut. Det er vitenskapelig illegitimt å henvise til en verdibasis som er unndratt fornuftig kritikk.

Fra 1970-tallet av kan man snakke om en normativ vending innenfor kultur- og samfunnsfag. Det ble lagt vekt på at alle kultur- og samfunnsfag også er normative (vurderende) disipliner. Det henvises gjerne til arbeider av forskere som filosofen John Rawls, sosiologen Jürgen Habermas, statsviteren 
Robert Dahl, samfunnsøkonomen Amartya Sen eller juristen Robert Alexy, for å illustrere denne vendingen. I norsk sosialteori var det Hans Skjervheim som på 1960-tallet først åpnet for dette perspektivet, i en påvisning av at sosiologi også er - og må være - en «kritisk» disiplin. ${ }^{3}$

Normative synspunkter kan styrkes, svekkes og endres som følge av overbevisende argumenter, både i dagligliv og i fagliv. Normativ argumentasjon om samfunnsmessige forhold er dermed en legitim, vitenskapelig oppgave. Det er mulig å gi gode grunner for at vi bør foretrekke demokrati fremfor diktatur. Det er både mulig og ønskelig å kritisere institusjonaliserte praksiser, som omskjæring. Kravene til normativ argumentasjon er like strenge som til deskriptiv, som krav til klarhet og sammenheng.

\section{Vitenskapen(e)s ethos og forskningsetiske retningslinjer}

Innenfor denne vitenskapenes enhet og forskjellighet hører de teologiske fag hjemme. Hva slags allmenne og særegne forskningsetiske krav bør rettes mot kultur- og samfunnsfag, inklusive teologi?

Akademiske grunnforskningsmiljøer er ikke verdifrie foretagender, men i en nærmere bestemt forstand normative, eller «moralske», prosjekter. Sannhet, konsistens, åpenhet for kritikk og erkjennelse av egen feilbarlighet er grunnleggende verdier, både i vitenskapsmoralen og ellers i samfunnet. «Moral» viser her til en allmenn kommunikasjonsmoral. I tråd med tradisjonen fra Arne Næss kan vi snakke om en saklighetsmoral. ${ }^{4}$ Habermas artikulerer en tilsvarende innsikt: «Den like fordeling av kommunikative friheter og kravet om oppriktighet $i$ diskurser innebærer argumentasjons-plikter og -rettigheter, ikke moralske plikter og rettigheter. ${ }^{5}$

Velfungerende vitenskapelige miljøer er preget av et sett av grunnleggende påbud, forbud, tillatelser og anbefalinger når det gjelder kommunikasjon og forvaltning av (u)enighet i beskrivelser, forklaringer og vurderinger. Innenfor vitenskapssosiologien nevnes ofte seks slike individuelle og institusjonelle fordringer, om upartiskhet, originalitet, kritiserbarhet, universalisme, offentlig eie av kunnskap og innsikt («kommunisme») og vitenskapelig ydmykhet. ${ }^{6}$

La oss se litt nærmere på disse allmenne forskningsetiske normene. 1) Upartiskhet. Den enkelte forsker og forskningsmiljøet skal være ledet av en interesse i å finne frem til gyldig kunnskap og innsikt, ikke etter å fremme eller tilpasse seg bestemte økonomiske, politiske, kirkelige og heller 
ikke PR-interesser på egen institusjons vegne. 2) Originalitet. Forskningsmiljøet skal tilstrebe å komme frem til ny kunnskap og innsikt. 3) Kritiserbarhet. Det skal være lov å sette spørsmålstegn ved, «kritisere», gyldigheten av alle påstander og antakelser. Ja, det er ikke bare tillatt, det er påbudt og forbudt å la være. 4) Universalisme. Det skal ikke spille noen rolle hvem det er som hevder et synspunkt. Det er tankeinnholdet som teller. Påstander om faktiske forhold eller normativ kritikk av bestemte praksiser (som omskjxring eller abort), skal vurderes etter overordnede standarder om sannhet, riktighet og sammenheng (konsistens). 5) Felleseiendom av kunnskap. Det er ingen privat eiendomsrett til vitenskapelig kunnskap. Det er en plikt å offentliggjøre og legge seg åpen for vurdering fra fagfeller og andre med relevant kompetanse. 6) Ydmykhet. Forskere skal være oppmerksomme på egen begrensethet og feilbarlighet, både i forhold til en stor og komplisert verden og til det hav av kunnskap og innsikt som tidligere, samtidige og fremtidige forskergenerasjoner representerer. I likhet med de andre normene, er også denne både av individuell og institusjonell karakter. ${ }^{7}$

Det er neppe hverken mulig eller ønskelig å (forsøke å) kodifisere en fullstendig liste over forskningsetiske normer. Den jeg her har nevnt, er åpenbart ikke fullstendig. Sentrale normer om individuell redelighet, institusjonell uavhengighet eller vitenskapens sannhetsbestrebelse, er f.eks. ikke tematisert. Vitenskapens normer kan ordnes på forskjellig måte. I den mest omfattende klargjøring av en generell vitenskapsmoral som vi har på et skandinavisk språk, skiller filosofen Knut Erik Tranøy (1986) mellom 9 grupper av normer. Disse kan imidlertid omformuleres og ordnes slik at de er i tydelig samsvar med resultatene fra liknende analyser, som Mertons seks normer, eller Habermas' fire betingelser for argumentasjon (åpenhet, likhet, sannferdighet og tvangfrihet). ${ }^{8}$

\section{Noen forskningsetiske problemer og utfordringer for teologiske fag}

I det følgende tar jeg opp fire forskningsetiske utfordringer for teologiske fag: kalling til vitenskapelige stillinger, forskningsekstern autoritet, forholdet mellom forskning og undervisning, og forholdet til presteutdanning.

(1) Institusjonalisering av kalling til vitenskapelige stillinger bryter med normen om universalisme. "Universalism finds further expression in the demand that careers be open to talent». ${ }^{9}$ Den generelle universalismenormen er at kjønn, rase, alder eller konfesjon ikke skal telle ved testing av teser 
eller ved tilsetting i vitenskapelige stillinger. Det normale skal være åpen utlysning, hvor den som i åpen konkurranse vurderes som best kvalifisert, tilsettes. Kvalifikasjoner avgjøres på grunnlag av åpent tilgjengelige, vitenskapelige publikasjoner.

Ensidig rekruttering fremmer sjelden vitenskapelig originalitet og produktivitet. Jeg tror så gjerne at det er riktig når Göran Bexell forteller at «alle vet» at mange av dagens beste Lutherforskere, er katolikker. ${ }^{10}$ Jeg ville ikke bli forundret hvis mange av de beste forskere på katolsk tradisjon er ikkekatolikker. Det er en vanlig erfaring at forskjellighet stimulerer til nye spørsmål, kunnskaper og innsikter.

(2) Vekten på universalisme i testing av teser og tilsettinger følger av kravene til vitenskapelige argumentasjonsprosesser. De forskningsetiske normer skal sikre at det bare er argumenter som teller i vurderingen av påstander og analyser. Det er en perversjon hvis det foreligger styrende synspunkter som ikke kan diskuteres, om de nå er av politisk, økonomisk eller religiøs karakter. Man kan ikke underlegge forskningsprosessen eksterne synspunkter, alle argumenter og forutsetninger skal kunne gjøres til gjenstand for kritisk analyse i den vitenskapelige diskurs. Som Sven Andersen så pregnant sier det, med hensyn til teologiske fag: «det er prisen for at have en videnskabelig teologi». ${ }^{11}$

Vitenskapsekstern autoritetskontroll kan også pålegges innenfra, ikke bare fra et styre, men også fra fagfeller. Ved MF hadde man et lærerråd som foretok en avstemning om Henriksens forskningsresultater: «I en enstemmig uttalelse fant rådet at hans argumentasjon ikke var overbevisende». ${ }^{12}$ Men hverken sannhets- eller riktighetsfordringer i argumentasjonsprosesser kan avgjøres ved flertallsuttalelser eller enstemmige resolusjoner. Vitenskapsmoralen krever også innsikt i muligheten for at vi alle kan ta feil samtidig, tilogmed i lengre perioder.

(3) Universiteter og vitenskapelige høgskoler er komplekse knippe-institusjoner, hvor et sett av faglige virksomheter er flettet inn i hverandre. Akademiske disipliner er både vitenskaper, studier, forskningsformidling, ekspertvirksomhet for brukere (profesjoner) og institusjonsforvaltning. Slike aktiviteter kan ofte bare atskilles analytisk. Et doktorgradsarbeid er både avslutning på et studium og et forskningsbidrag. Det kan derfor være vanskelig å si hvor grensene for forskningsetikken går i skjæringsflatene mellom forskjellige former for faglig virksomhet. ${ }^{13}$

En ambisjon i universiteter og høyskoler, er at undervisningen skal være forskningsbasert. Derved preges også undervisning og veiledning av de 
samme eller tilsvarende normer som preger forskningen. Det er derfor kritikkverdig om fagpersoner tas vekk fra forskningsbasert undervisning fordi de har konvertert til en annen konfesjon eller religion eller har kommet frem til synspunkter som strider mot allment aksepterte oppfatninger i en institusjon eller tradisjon. Jeg har ikke sett gode grunner for at en forsker ved en protestantisk institusjon bør fratas undervisnings- og veiledningskompetanse på sine spesialområder ved overgang til katolisismen. De konflikter som er kjent fra katolske institusjoner hvor forskere (som Hans Küng) er fratatt undervisningsoppgaver fordi de ikke har akseptert pavens ufeilbarlighet, tydeliggjør problemet. Heller ikke akademisk undervisning og veiledning skal være bundet av en fagekstern autoritet som ikke er underkastet «det bedre arguments tvangfrie tvang». ${ }^{14}$

(4) En annen skjæringsflate i akademiske institusjoner går på forholdet mellom vitenskap og profesjon (ekspertvirksomhet). Alle vitenskaper kan danne grunnlag for ekspertvirksomhet, f.eks. i form av at en fagperson gir råd til en bruker. Forskning og undervisning må være lagt opp slik at den også tjener profesjonsutdanningen ved et fakultet. I slik virksomhet møtes altså tre fagetikker: forskningsetikk, studieetikk og profesjonsetikk Et eksempel på slik tilpasning er den omfattende omlegging av undervisningen som fant sted ved Det medisinske fakultet ved Universitetet i Oslo høsten 1996. Her fikk man overgang til problembasert læring og tilrettelegging med sikte på at studiet bedre enn tidligere primært skulle tjene til å utdanne leger, ikke medisinske forskere. Hensynet til brukerne står sentralt i slike prosesser. Slik samordning av forskjellig faglig virksomhet er særlig tydelig i profesjonsfag som medisin, juss, psykologi, siviløkonomi, teologi og ingeniørfag. Samordningen kan medføre press mot forskningsetiske normer fra brukere (klienter) med sterke interesser.

Hvordan kan slike relasjoner organiseres ved teologiske fakulteter og høgskoler som er konfesjonsbundet og ansvarlig for presteutdannelse? Hva slags institusjonelle ordninger kreves, hvilke kulturer må utvikles og opprettholdes? Kan alle de forskjellige hensyn samordnes slik at kravene til fri forskning ikke undergraves? Bør noen oppgaver legges til institusjoner utenfor de akademiske? Konfliktene ved noen norske institusjoner viser at dette er et krevende felt med betydelige utfordringer. 


\section{Kultur- og samfunnsfag som gyldighetsorienterte disipliner}

Svend Andersen hevder at teologien som universitetsfag nødvendigvis er en normativ disiplin. For å klargjøre sitt synspunkt sammenligner han teologi og religionsvitenskap og innfører begrepet gyldighetsnormativitet. Han tar opp spørsmålet om bestemte religiøse påstander er sanne eller religiøse erfaringer genuine. Med henvisning til Clifford Geertz hevder han at det klassiske religionsvitenskapelige svaret, er at slike spørsmål ikke engang kan stilles, gitt de begrensninger et vitenskapelig perspektiv krever. Religionsvitenskapen er dermed deskriptiv. Til forskjell fra dette, hevder Andersen, er teologien normativ fordi den betrakter sitt emne, kristen tro og tradisjon, «med henblikk på dens iboende gyldighetspretensjon». ${ }^{15}$

Andersens tolking av Geertz er rimelig nok. Men med henvisning til den normative vending som ble omtalt foran, er det ikke noe spesielt for teologiske fag at de er normative disipliner. Alle kultur- og samfunnsfag, inklusive religionsvitenskap, er både normative og deskriptive disipliner.

Men hva betyr det i forskningspraksis, i forskningens hverdag, at et fag er normativt? Andersen spesifiserer ikke her hva en slik gyldighetsorientert, normativ tilnærming kan innebære og gir ikke eksempler på slik forskning. Men han gir en generell henvisning til Habermas's analyse av talehandlingers gyldighet. Jeg avslutter med en presentasjon av én av de måtene vi kan gå videre på et slikt grunnlag.

Forskere setter frem gyldighetsfordringer, f.eks. påstander om faktiske inntektsforskjeller i en bransje eller vurdering av disse. Verdistandardene er mange. Man kan for eksempel spørre om forskjellene stimulerer til produktivitet og nyskaping eller man kan spørre om de er rettferdige. Deskriptive og normative gyldighetsfordringer diskuteres i forskersamfunnet. Er beskrivelsene i samsvar med de faktiske forhold - er de sanne? Strider en praksis mot grunnleggende menneskerettigheter eller ikke?

«Undersøkelsesobjektene», de som utforskes, setter også frem gyldighetsfordringer. Industriarbeidere og toppledere i bedrifter har f.eks. oppfatninger om hva de faktiske inntektsfordelinger er og om de er rettferdige. Kultur- og samfunnsviteren kan dermed både drøfte gyldigheten av andre forskeres oppfatninger og de utforskedes oppfatninger. Naturvitere kan bare delta i den første type diskusjon, de kan ikke diskutere med det utforskede felt.

Vi får bare tilgang til et sosialt og kulturelt felt ved å forstå aktørers grunner. ${ }^{16}$ For i det hele tatt å kunne beskrive grunner, må vi også ha et 
begrep om hva som skal til for å kunne ta stilling til det som hevdes eller forutsettes i talehandlinger. ${ }^{17}$ To sentrale gyldighetsstandarder er av konstaterende og vurderende karakter. Konstaterende gyldighetsfordringer dreier seg om påstander om at noe faktisk er eller var tilfelle, om hvorfor noe endret seg eller forble stabilt, og antakelser om sannsynlig utvikling. Normative gyldighetsfordringer omfatter vurderinger av faktiske forhold, inklusive vurdering av normer og verdier som praktiseres i det studerte felt.

La oss holde oss til dem som utforskes, om det nå er foreldre, forretningsfolk eller forfattere av religiøse skrifter. Kultur- og samfunnsviteren kan ikke være en utenforstående tilskuer fra Mars i drøftingen av gyldighetsfordringer i et felt som utforskes. Da ville man ikke engang kunne beskrive grunner. Beskrivelse og fortolkning av talehandlingers betydning og vurdering av deres gyldighet, kan ikke skilles helt fra hverandre. "Vi forstår en talehandling......dersom vi vet hva som gjør den akseptabel». ${ }^{18}$ Drøfting av talehandlinger omfatter også saksorientert drøfting av påstanders sannhet (konstaterende) og normers riktighet (vurderende).

La meg konkretisere fremstillingen ved å bruke noen synspunkter fra et sentralt teologisk (Crossan) og sosiologisk (Merton) forfatterskap. Hvor mye og hva i evangelienes lidelseshistorie, fra Getsemane til Golgata, er sannsynlig historie og hvor mye er historisk fiksjon, om det er i form av kristen oppbyggelse eller historisering av profetier i den hebraiske bibel? Det er altså et spørsmål om sannhetsfordringer. Crossan fortetter sitt synspunkt i tesen om at $80 \%$ er historisk fiksjon, mens $20 \%$ viser til virkelige historiske begivenheter. Han argumenterer for at evangelistenes påstand om at Jesus ble arrestert og henrettet av den romerske okkupasjonsmakten, viser til historiske begivenheter. Men påstandene om at det var en rettergang, ja til og med to, er neppe riktige. «It is not just the content of the trial(s) but the very fact of the trial(s) that I consider to be unhistorical». ${ }^{19}$ Påstandene om rettergang(er) er, ifølge Crossan, i for dårlig samsvar med hva vi ellers vet, f.eks. om romersk imperialisme, romersk straffepraksis eller hvordan Pilatus faktisk styrte.

I Paulus-brevene fremsettes det en rekke påbud, anbefalinger og tillatelser, f.eks. om forholdet mellom menn og kvinner, om det nå er i familien, i menigheten eller som apostler. En elementær vurdering av slike normative gyldighetsfordringer, er å undersøke om de er i motstrid med hverandre. Crossan og Reed argumenterer for at Paulus-brevene er preget av selvmotsigelser når det gjelder kvinners forhold til menn i familier og menigheter. De fleste steder insisterer Paulus på likeverdighet, mens han noen steder krever 
underordning. Men heller ikke Paulus kan bryte kontradisjonsprinsippet. Hvis tesen er holdbar må antitesen være uholdbar. Crossan og Reed forklarer forøvrig inkonsistensen med tilføyelser fra senere forfattere. De argumenterer for at Paulus ikke var selvmotsigende, men ønsket radikal likestilling i de kristne menigheter.

Vurdering av gyldighetsfordringer fremsatt i en annen tid, krever arbeid med å sette seg i aktørenes sted, slik at man kan gi en rimelig tolking av deres påstander. For mange samfunnsvitere har det falt naturlig å neglisjere de religiøse utsagn som 1600-tallets naturvitere kom med. Utsagnene, som vitner om at de er troende kristne, blir tolket som konvensjonelle fraser eller tilpasninger til en mektig kirke- og kongemakt. De blir ikke akseptert som oppriktig uttrykk for forskernes motivasjon. Merton viser at dette generellt er en urimelig tolking: «such an interpretation is possible only if one neglects to translate oneseself within the framework of seventeenth-century values». ${ }^{20}$ Kristen tro var en vesentlig del av disse naturviternes virkelighetsforståelse.

Vi møter samme type utfordring når vi skal fortolke skrifter av romerske og jødiske forfattere fra begynnelsen av vår tidsregning. Hvordan skal vi tolke Matteus og Lukas når de hevdet at Jesu guddommelige unnfangelse var et historisk faktum? Forutsatte de at dette utelukkende hadde skjedd med Jesus, og ikke også med andre? Crossan argumenterer for at evangelistene ikke kan ha ment at dette var noe særegent for Jesus. Hvis dette er en rimelig tolking av deres utsagn, er det knapt noen i dag som vil akseptere deres påstand som holdbar virkelighetsbeskrivelse.

Crossan fester også oppmerksomheten om at man har et forskningsetisk problem, hvis man ikke drøfter kilder ut fra de samme vitenskapelige standarder. Man kan ikke bare avvise historien om keiser Augustus's guddommelige unnfangelse, men godta - eller stille seg åpen for - den samme type historie om Jesus. Crossans tolkning, som kristen teolog, er denne: «I do not accept the divine conception of either Jesus or Augustus as factual history, but I believe that God is incarnate in the Jewish peasant poverty of Jesus and not in the Roman imperial power of Augustus». ${ }^{21}$

Jeg har søkt å illustrere noen aspekter ved hva gyldighetsorientert vurdering av de individer, institusjoner og tradisjoner som utforskes, kan bety. Illustrasjoner kunne like godt vært valgt fra andre områder, som historiske vurderinger av klokskapen (eller mangelen på dette) i den engelske regjernings handlinger (og passivitet) på andre halvpart av 1700-tallet, en prosess som ledet frem til den amerikanske uavhengighetserklæringen. Det kan også 
dreie seg om samtidige analyser, som normativt-empiriske studier av sannhetsgehalten i den amerikanske regjerings uttalelser om masseødeleggelsesvåpen $\mathrm{i}$ Irak eller rettsvitenskapelige studier av den folkerettslige legitimitet $\mathrm{i}$ beslutningen om invasjon i Irak våren 2003. Ifølge den normative vending er alle kultur- og samfunnsfag, inklusive teologi og religionsvitenskap, også normative disipliner. Men dette åpner hverken for postmoderne relativisme eller premoderne rettroenhet. Det kreves rasjonell normativ argumentasjon, åpen for egen feilbarlighet.

Ragnvald Kalleberg (f. 1943) er professor i sosiologi ved Universitetet i Oslo. Han har arbeidet med vitenskapssosiologi (vitenskapsteori, faghistorie, forskningsetikk, kunnskapsorganisasjoner) og organisasjonssosiologi (arbeidsmiljø, demokratisering, ledelse). Tre relevante arbeider i tillegg til dem i litteraturhenvisningene, er «Kierkegaard som samfunnstenker» (Nytt Norsk Tidsskrift, nr. 2, 2003), "Om vitenskapelig ydmykhet» i NESH-publikasjon om samisk forskning (2003), og «Universities: Complex Bundle Institutions and the Projects of Enlightenment»(Comparative Social Research, 2000). Han har vært formann i NESH siden 2000. e-post: ragnvald.kalleberg@sosiologi.uio.no

NOTER

1 MF 2004, s. 13.

2 For utdyping her og i det følgende, se kap. 4, samt kap. 5-7 i Engelstad m. fl. 2005.

3 Om den normative vending i kulturog samfunnsfag, se Engelstad m. fl. 2005, kap. 1.4, 4.4, 5.3/4, 7.1, 7.3, del IV. Se også Skjervheim (1996).

4 Næss 1959, kap. 6.

5 Habermas 1999, s. 210.

6 Se Merton 1973, kap. 13 og 14.

7 Se Merton 1973, s. 303-5 og Kalleberg 2003, s. 196- 201.

8 Se Habermas 1999, s. 210.

9 Merton 1973, s. 272

LITTERATUR
Andersen, Svend (2003): «Teologiens normativitet: Grænser for videnskabeligt tilladte standpunkter?», i NESH 2003. (Også i Kirke og kultur, nr. 5/6, 2002).

Bexell, Göran (2003): «Teologi - universitet - vitenskap", i NESH 2003. (Også i Kirke og kultur, nr. 5/6, 2002).
10 Bexell 2003, s. 37.

11 Andersen 2003, s. 16.

12 Se Kvanvig 2002, s. 450.

13 Kalleberg 2003, s. 189-192.

14 Habermas 1999, s. 204

15 Andersen 2003, s. 18.

16 Se Engelstad m. fl., 2005, kap. 6.1

$17 \AA$ snakke er en form for (tale)hand-

ling. For en introduksjon til talehandlingsteori, se Kalleberg 1999, s. 20-27, Habermas 1999, s. 137-171.

18 Habermas 1999, s. 152

19 Crossan 1995, s. 117

20 Merton 1968, s. 631.

21 Crossan 1998, s. 26-29.

Crossan, John Dominic (1995): Who killed Jesus? Exposing the Roots of Anti-Semitism in the Gospel Story of the Death of Jesus. Harper, San Francisco.

Crossan, John Dominic (1998): The Birth of Christianity. San Francisco: Harper. 
Crossan, John Dominic, Jonathan L. Reed (2005): In Search of Paul. How Jesus's Apostle Opposed Rome's Empire with God's Kingdom. SPCK, London.

Dokka, Trond Skard (2001): «Menighetsfakultetet ved et veiskille». Kronikk i Aftenposten 1. november.

Engelstad, Fredrik, Carl Erik Grenness, Ragnvald Kalleberg, Raino Malnes (2005): Introduksjon til samfunnsfag. Vitenskapsteori, argumentasjon og faghistorie. Gyldendal Akademisk, Oslo.

Habermas, Jürgen (1999): Kraften i de bedre argumenter. Gyldendal Akademisk, Oslo.

Henriksen, Jan-Olav (2001): «Kirke og homofili - er det mulig å tenke om igjen?». Kronikk i Aftenposten 13. januar.

Kalleberg, Ragnvald (1999): «Moderne samfunns utfordringer.» Innledning til Habermas 1999.

Kalleberg, Ragnvald (2003): «Håndtering og forebygging av vitenskapelig uredelighet», s.185-211 i K. Ruyter red., Forskningsetikk. Beskyttelse av enkeltpersoner og samfunn. Gyldendal Akademisk, Oslo.

Kvanvig, Helge S. (2002): «Kollegial avsporing og Menighetsfakultetets basis", s. 449-451 i Kirke og kultur, nr. 5/6.
MF (2004): «Akkreditering av det teologiske menighetsfakultet som vitenskapelig høgskole. Uttalelse til «Rapport fra sakkyndig komité» fra styret ved MF i møte 4. August 2004.» Uttalelse til NOKUT.

Merton, Robert (1968): «Puritanism, Pietism, and Science», s. 628-659 i Social Theory and Social Structure. The Free Press, New York.

Merton, Robert (1973): The Sociology of Science. The Free Press, New York.

NESH (1999): Forskningsetiske retningslinjer for samfunnsvitenskap, jus og humaniora. De nasjonale forskningsetiske komiteer. Oslo.

NESH (2003): Akademisk frihet i teologisk forskning. Rapport nr. 3. De nasjonale forskningsetiske komiteer. Oslo. (Se Kirke og kultur, nr. 5/6, 2002).

Næss, Arne (1959): Endel elementare logiske emner. Universitetsforlaget, Oslo.

Skarsaune, Oskar (2001): «Forskningens vilkår ved de teologiske fakultetene». Kronikk i Aftenposten 12. november. Skjervheim, Hans (1996): «Sosiologien som vitskap - positiv eller kritisk disiplin?», s. 200-213 i Deltakar og tilskodar. Aschehoug forlag, Oslo.

Tranøy, Knut Erik (1986): Vitenskapensamfunnsmakt og livsform. Universitetsforlaget, Oslo. 